\title{
PERANAN PERKEMBANGAN INOVASI FINANSIAL SISTEM PEMBAYARAN DALAM MEMPENGARUHI PERMINTAAN UANG DI INDONESIA
}

\author{
Endah Siska Aristiyowati \\ endah.siska@alumni.ui.ac.id \\ Telisa Aulia Falianty \\ Fakultas Ekonomi dan Bisnis, Universitas Indonesia
}

\begin{abstract}
This paper examines the dynamic interaction between financial innovation development in the payment system to money demand function especially for currency and narrow money, from 2007-2017 using Indonesia monthly data. This research based on Baumol (1952) and Tobin (1956) and Lippi and Secchi (2009) theory which stated that improvement of technology in the payment system will lead to a decrease in transaction demand for money. From estimation result using Vector Error Correction Model (VECM) method, study reveals that tremendous development in the payment system on the last eleven years i.e Real Time Gross Settlement, Clearing, Automatic Teller Machine (ATM) or Debit Card, Credit Card and electronic money using several proxies, such as using transaction value (with and without clearing), total transaction value, transaction volume, ratio of financial innovation in the payment system to Gross Domestic Product (GDP), broad money (M2) to narrow money (M1) ratio, ratio of financial innovation in the payment system to narrow money (M1) will decrease currency and narrow money (M1). Analysis of the financial innovation in the payment system role in affecting money demand (currency and narrow money) is very important so that money demand function is not misspesificied and in determining monetary policy has considered the development of payment system technology.
\end{abstract}

Key words: financial innovation, money demand, currency, payment system

\begin{abstract}
ABSTRAK
Artikel ini mengkaji interaksi dinamis antara pengembangan inovasi keuangan dalam sistem pembayaran terhadap fungsi permintaan uang khususnya currency dan permintaan uang dalam arti sempit (M1) dari tahun 2007-2017 menggunakan data bulanan di Indonesia. Penelitian ini menggunakan teori Baumol (1952) dan Tobin (1956) dan Lippi dan Secchi (2009) yang menyatakan bahwa teknologi sistem pembayaran dapat menurunkan permintaan uang. Dari hasil estimasi dengan menggunakan metode Vector Error Correction Model (VECM), disimpulkan bahwa perkembangan pada sistem pembayaran dalam sebelas tahun terakhir yaitu Real Time Gross Settlement, Kliring, Automatic Teller Machine (ATM) atau Kartu Debet, Kartu Kredit dan uang elektronik dengan menggunakan beberapa proxy yaitu antara lain menggunakan nilai transaksi (dengan dan tanpa kliring), total nilai transaksi, volume transaksi, rasio inovasi finansial terhadap Gross Domestic Product (GDP), rasio Broad Money (M2) terhadap Narrow Money (M1), rasio inovasi finansial terhadap Narrow Money (M1) akan mengurangi permintaan currency dan permintaan uang dalam arti sempit (M1). Analisis mengenai pengaruh inovasi finansial sistem pembayaran terhadap permintaan uang (currency dan narrow money) sangat penting agar money demand function tidak misspesificied dan agar dalam penetapan kebijakan moneter telah mempertimbangkan perkembangan teknologi sistem pembayaran.
\end{abstract}

Kata kunci: inovasi finansial, permintaan uang, uang tunai, sistem pembayaran

\section{PENDAHULUAN}

Inovasi finansial adalah tindakan menciptakan dan mempopulerkan instrumen finansial baru, serta institusi, market dan teknologi finansial yang baru, inovasi finansial juga telah menjadi economic landscape 
dalam beberapa dekade terakhir (Tufano, 2003). Dalam penelitiannya, Tufano (2003) menyebutkan bahwa terdapat dua tipe atau kategori inovasi finansial yaitu inovasi dari sisi produk dan inovasi dari sisi proses.

Inovasi finansial dari sisi produk antara lain yaitu instrumen keuangan dengan contoh produk derivative. Sedangkan untuk inovasi finansial dari sisi proses terdiri dari beberapa kategori yaitu kategori pertama adalah cara inovatif untuk mendistribusikan produk keuangan seperti sekuritisasi dan credit scoring, kategori kedua yaitu metode inovatif untuk transaksi finansial atau keuangan seperti business reporting, dan electronic financial analysis. Kategori ketiga yaitu new payment techniques atau teknik pembayaran baru yang mencakup sistem pembayaran berupa ATM, internet banking, debitataucredit card, e-money, dan e-bills pay.

Salah satu inovasi finansial yang termasuk kategori proses dan berkembang pesat dalam dua dekade terakhir ini adalah inovasi finansial dalam sistem pembayaran. Inovasi finansial sistem pembayaran di Indonesia terdiri dari Sistem Pembayaran Nilai besar yang meliputi Real Time Gross Settlement (RTGS) dan Kliring, kemudian Sistem Pembayaran retail yang terdiri dari instrumen ATM atau Debit Card, Credit Card, E-money, direct debit, credit transfer dengan infrastruktur yaitu mesin ATM, EDC, Internet dan mobile banking serta branchless banking. Tipe inovasi sistem pembayaran juga disebut sebagai sistem pembayaran non tunai.

Penggunaan sistem pembayaran telah digunakan secara luas terutama dalam tiga sampai lima tahun terakhir. Instrumen sistem pembayaran yang meliputi alat pembayaran menggunakan kartu, mengalami peningkatan cukup pesat yaitu untuk nilai transaksi kartu debet pada tahun 2016 adalah sebesar Rp 155,4 triliun, atau meningkat sebesar $237 \%$ dari tahun 2009, nilai transaksi kartu kredit tahun 2016 adalah sebesar Rp 26.3 triliun, meningkat sebesar $171 \%$ dari tahun 2009, kemudian nilai transaksi e-money pada tahun 2016 adalah
Rp749 miliar atau meningkat sebesar $3.361 \%$ dari tahun 2009. Disamping itu dalam dua belas tahun terakhir juga terdapat penurunan komposisi currency (Uang kartal di luar Bank Umum dan BPR) yang merupakan komponen dari M1 (uang dalam arti sempit) dari sebesar $44.3 \%$ \% di tahun 2004 menjadi $41,06 \%$ di tahun 2016. Trend penurunan komposisi currency tersebut dapat terlihat pada Grafik 1 berikut ini:

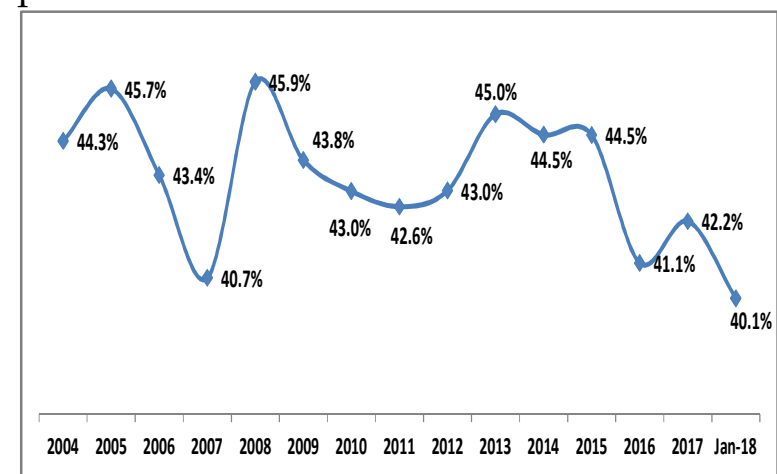

\section{Grafik 1}

Perkembangan komposisi currency terhadap M1

Sumber: Bank Indonesia Tahun 2004-2018

Kemudian terkait dengan perkembangan inovasi finansial sistem pembayaran dapat dilihat pada Grafik 2 berikut ini:

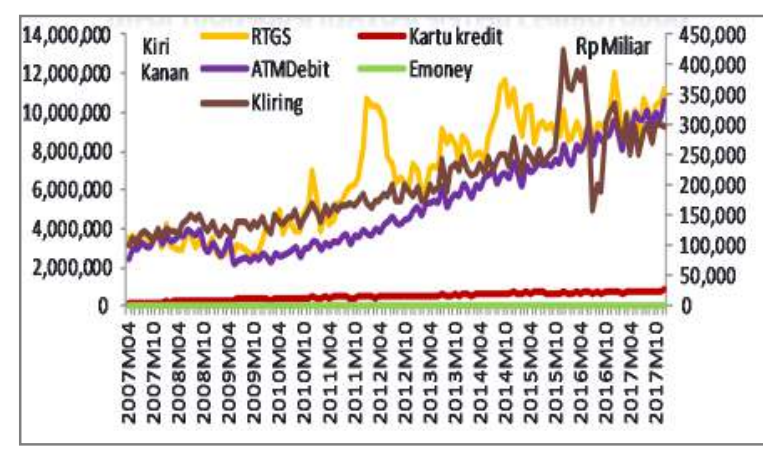

Grafik 2

Perkembangan transaksi Inovasi Finansial Sistem Pembayaran

Sumber: Statistik Sistem Pembayaran BI Tahun 2007-2017

Dari Grafik 2 digambarkan bahwa terdapat peningkatan pesat pada inovasi finansial sistem pembayaran selama periode penelitian. Namun pada bulan Juli 2016, 
terdapat penurunan kliring, dikarenakan adanya perubahan ketentuan dan pembatasan nominal transaksi RTGS dan Kliring. Selain itu, pada triwulan pertama tahun 2016 juga terdapat penurunan GDP growth menjadi 4,94\%. Pada tahun 2007-2009 nilai transaksi inovasi finansial sistem pembayaran terlihat masih cukup kecil, hal ini dikarenakan adanya pengaruh dari krisis global tahun 2008, namun setelah itu transaksi inovasi finansial sistem pembayaran mengalami peningkatan kembali.

Perkembangan inovasi keuangan berbasis teknologi pada sektor perbankan memiliki tujuan untuk memenuhi kebutuhan nasabah akan produk perbankan yang lebih mudah digunakan oleh nasabah dan mengurangi biaya dalam melakukan transaksi perbankan. Namun, perkembangan inovasi finansial di sektor perbankan memiliki pengaruh pada permintaan uang. Estimasi fungsi permintaan uang menggunakan pendekatan teori money demand tradisional dengan tidak mengikutsertakan variabel inovasi finansial, dapat membuat money demand misspecified, kemudian penetapan mekanisme kebijakan moneter juga bergantung kepada stabilitas dan predictability dari fungsi demand for money (Arrau dan Gregorio, 1993). Oleh karena itu, penelitian mengenai pengaruh inovasi finansial sistem pembayaran terhadap permintaan uang (currency dan M1) sangat penting dilakukan mengingat perannya dalam proses penetapan kebijakan moneter.

Dalam penelitian pada sekitar tiga dekade terakhir telah digunakan beberapa proxy untuk mengukur pengaruh inovasi finansial terhadap permintaan uang namun masih dilakukan secara individual atau tidak terintegrasi. Beberapa peneliti yang menggunakan proxy yaitu ATM atau kartu debet yaitu Lieberman (1977), Daniels dan Murphy (1994), Attanasio et al. (2002), Stix (2004), Fischer (2007), Columba (2009), Lippi dan Secchi (2009), Yazgan dan Yilmazkuday (2009), Nagayasu (2012), Carbo-Valverde dan Rodriguez-Fernandez (2014), dan David et al. (2016). Sedangkan peneliti yang menggunakan proxy credit card diantaranya Duca dan Whitesell (1995); Shiva dan Durai (2017). Rinaldi (2001) menggunakan proxy credit card, kemudian menambahkan debit card dan payment card terminal sebagai tambahan proxy. Pramono et al. (2006) menggunakan proxy ATM atau kartu debet dan kartu kredit untuk menguji pengaruhnya terhadap narrow money (M1). Penelitian Oyelami dan Yinusa (2013) menggunakan proxy debit card, point of sales (POS), internet banking dan mobile money dan melakukan pengujian pengaruh inovasi finansial terhadap currency.

Penelitian Sahabat (2009) mulai mengakomodir sistem pembayaran lainnya selain ATM atau kartu debet dan kartu kredit, dengan menambahkan proxy yaitu RTGS, dan kliring untuk mengukur pengaruhnya terhadap narrow money (M1). Proxy sistem pembayaran tersebut, dihitung dengan menggunakan jumlah transaksi untuk masing-masing proxy. Kemudian Aliha (2017) menggunakan tiga kategori utama yaitu payment instrument yang meliputi kartu kredit, kartu debet, charge card, dan e-money, kategori kedua adalah payment system yang terdiri dari transaksi Rentas, Interbank Giro, FPX dan direct debit, serta kategori ketiga adalah payment channels yang meliputi transaksi ATM, transaksi mobile banking dan transaksi internet banking. Aliha (2017) menggunakan jumlah atau nilai transaksi dari masing-masing proxy untuk kategori payment instrument, payment system, dan payment channels.

Dari beberapa studi sebelumnya, proxy yang digunakan cukup beragam, belum terintegrasi, dan masih menggunakan perhitungan berdasarkan jumlah atau nilai transaksi dan jumlah dari inovasi finansial. Research gap dari penelitian ini adalah bahwa penelitian mengenai pengaruh inovasi finansial sistem pembayaran terhadap currency, dan M1 merupakan hal yang penting dalam penetapan kebijakan moneter agar money demand function tidak misspecified, dan selama ini belum terdapat 
penelitian menggunakan proxy inovasi finansial sistem pembayaran yang lengkap dan komprehensif serta menggunakan beberapa alternatif perhitungan inovasi finansial. Adapun dalam penelitian ini, digunakan berbagai metode pengukuran atau rasio dengan ruang lingkup proxy yang terintegrasi yaitu: Alat Pembayaran Menggunakan Kartu (APMK) (terdiri dari ATM atau debit card, credit card), RTGS, kliring, dan e-money. Beberapa proxy tambahan yang digunakan dalam penelitian ini mencakup rasio inovasi sistem pembayaran terhadap GDP, rasio inovasi sistem pembayaran terhadap M1, rasio M2 terhadap M1.

Research question untuk penelitian ini yaitu: (1) Bagaimana interaksi dinamis antara masing-masing variabel inovasi finansial atau masing-masing tipe inovasi finansial sistem pembayaran terhadap permintaan currency?; (2) Bagaimana interaksi dinamis antara masing-masing variabel inovasi finansial atau masing-masing tipe inovasi finansial sistem pembayaran terhadap permintaan uang dalam arti sempit (M1)?; (3) Apakah proxy atau indikator yang paling tepat untuk mengukur pengaruh inovasi sistem pembayaran terhadap permintaan uang?.

Penelitian ini memiliki tujuan yaitu mengidentifikasi interaksi dinamis inovasi finansial sistem pembayaran terhadap permintaan currency, dan permintaan uang dalam arti sempit (M1), serta mengindentifikasi proxy atau indikator yang sesuai untuk mengukur inovasi finansial sistem pembayaran. Penelitian ini sangat dibutuhkan agar pembuat kebijakan dapat menetapkan instrumen dan kebijakan moneter yang tepat dengan telah mempertimbangkan kemajuan teknologi yang termasuk ke dalam inovasi finansial sistem pembayaran.

\section{TINJAUAN TEORETIS}

Teori yang mendasari penelitian mengenai pengaruh inovasi finansial sistem pembayaran terhadap permintaan uang untuk transaksi adalah teori yang disampaikan oleh Baumol (1952) dan Tobin
(1956) serta teori yang disampaikan dan diperbaharui oleh Lippi dan Secchi (2009).

Kerangka teori untuk penelitian ini dimulai dari penelitian yang dilakukan oleh Baumol (1952) dan Tobin (1956) mengenai permintaan uang untuk transaksi dengan menggunakan asumsi bahwa individu memiliki pilihan untuk memegang money (M) atau bonds (B), tidak terdapat uncertainty, $\mathrm{Y}$ adalah nominal jumlah uang yang akan dibelanjakan, $\mathrm{W}$ adalah jumlah uang yang ditarik pada setiap periode, Average money balances yaitu $M$ adalah sebesar $1 / 2 W$, karena setiap dilakukan penarikan, dibelanjakan dengan pola pengeluaran yang sama. Kemudian $\mathrm{M}+\mathrm{B}=1 / 2 \mathrm{Y}$, karena $1 / 2 \mathrm{Y}$ diasumsikan telah dibelanjakan. Jumlah bonds holdings adalah sebesar $1 / 2 Y-1 / 2 W$. Kemudian jumlah penarikan adalah sebesar $n=Y / W$.

Dalam melakukan penarikan dana, terdapat biaya yang perlu dikeluarkan yaitu biaya brokerage cost, yang antara lain meliputi biaya fixed atau biaya tetap dan biaya variable. Sehingga total cost (TC) dapat dijabarkan sebagai berikut:

$T C=$ Transaction cost + Interest foregone

Transaction cost $=\left(B_{0}+B_{1} W\right) n$

Dimana $B_{0}$ adalah fixed cost yaitu biaya tetap dimana pada setiap kali penarikan, akan dikenakan sebesar biaya tetap tersebut. Kemudian terdapat biaya variabel, yaitu sebesar $B_{1} . W$, yaitu biaya yang dikenakan setiap nominal penarikan. Sedangkan untuk interest cost atau interest foregone yaitu sebesar R.M atau R. Watau2. Sehingga total cost adalah sebesar:

$T C=R M+\left(B_{0}+B_{1} W\right) n$.

$T C=R \frac{W}{2}+\left(B_{0}+B_{1} W\right) n$

$T C=R \frac{W}{2}+B_{0} \cdot \frac{Y}{w}+B_{1} \cdot Y$

Individu dalam menentukan untuk memegang uang dalam jumlah tertentu pada setiap penarikan dana, melakukan minimisasi biaya dengan penjelasan sebagai berikut:

First order condition untuk minimisasi total cost:

$\frac{\partial T C}{\partial W}=\frac{R}{2}-B_{0} \cdot Y \cdot W^{-2}=0$ 


$$
\begin{aligned}
& \frac{\partial T C}{\partial W}=\frac{R}{2}-\frac{B_{0} Y}{W^{2}}=0 \\
& W^{2}=\frac{2 B_{0} Y}{R} \\
& W=\sqrt{\frac{2 B_{0} Y}{R}} \\
& W=\left[\frac{2 B_{0} Y}{R}\right]^{1 / 2}
\end{aligned}
$$

Sehingga money balance for transaction adalah sebesar:

$M^{t r}=\frac{1}{2} W=\left(\frac{1}{2} B_{0}\right)^{1 / 2} Y^{1 / 2} R^{-1 / 2}$

Dalam real term dinyatakan sebagai berikut:

$\frac{M^{t r}}{P}=\left(\frac{1}{2} b_{0}\right)^{1 / 2} y^{1 / 2} R^{-1 / 2}$

dimana $\mathrm{M}^{\mathrm{tr}}$ adalah permintaan uang untuk transaksi, $\mathrm{P}$ adalah harga, $\mathrm{b}_{0}$ adalah real brokerage cost, $y$ adalah pendapatan riil, dan $\mathrm{R}$ adalah suku bunga nominal.

$\frac{\partial M^{t r}}{\partial b_{0}}>0$, memiliki implikasi bahwa apabila terdapat peningkatan pada brokerage cost, maka akan terdapat peningkatan pada jumlah money balances, atau jumlah uang yang dipegang oleh individu. Hal ini disebabkan karena jika terdapat peningkatan biaya, maka individu akan memilih untuk memegang uang lebih banyak sehingga hal tersebut akan meningkatkan transaction demand for money.

Penggunaan dari inovasi berbasis teknologi seperti ATM, transfer dana secara elektronik, debet card dan online payment, akan mengurangi brokerage cost dari menggunakan rekening giro (demand deposits) dan mengurangi permintaan uang untuk transaksi (Handa, 2009). Berkaitan dengan hubungan antara money demand, brokerage cost dan perkembangan technology, terdapat teori yang disampaikan oleh Lippi dan Secchi (2009) mengenai transaction technology pada transaction demand for money yang merupakan kelanjutan dan pembaharuan dari teori Baumol (1952) dan Tobin (1956), dengan penjelasan sebagai berikut: Individu dalam melakukan penarikan dana akan meminimisasi biaya dengan rumus:

Min, $R M+b . n(W, Y)$ dimana $\mathrm{R}$ adalah nominal interest rate, $\mathrm{n}(\mathrm{W}, \mathrm{Y})$ adalah jumlah penarikan ke bank yaitu sebesar $n=Y / W, Y$ adalah nominal expenditure, $\mathrm{W}$ adalah jumlah penarikan per periode, $\mathrm{M}$ adalah money balance, $\mathrm{b}$ adalah brokerage cost. RM merupakan opportunity cost atau foregone interest, sedangkan $\mathrm{b}$. $\mathrm{n}$ $(\mathrm{W}, \mathrm{Y})$ adalah brokerage cost atau trasnsaction cost. Marginal withdrawal benefit of money merupakan FOC dari $n(W)$ yaitu -n' (W).

$\mathrm{n}$ adalah jumlah berapa kali penarikan atau jumlah trip ke bank untuk withdrawal dimana:

$n=Y / W$.

Dengan adanya peningkatan teknologi, maka jumlah withdrawal atau trip peningkatan technology merupakan maksimisasi dari pilihan dengan persamaan sebagai berikut:

$n_{p}(W, Y)=\max \left(\frac{Y}{W}-p, 0\right)$

Dimana $\mathrm{p}$ merupakan faktor pengurang dari jumlah trip yang mencerminkan adanya peningkatan teknologi.

Arti dari pilihan maksimisasi di atas adalah bahwa individu akan memilih nilai maksimal mana yang paling besar antara $\frac{Y}{W}-p$ atau 0 .

Implikasi dari maksimisasi pilihan di atas adalah:

a. Jika $\mathrm{p}=0$ artinya tidak terdapat technology, maka jumlah berapa kali penarikan atau n akan menjadi $\frac{Y}{W}$ dan brokerage cost akan menjadi sebesar $b \cdot \frac{Y}{W}$.

b. Jika $\mathrm{p}>0$ atau nilai $\mathrm{p}$ adalah positif, artinya terdapat peningkatan technology, maka jumlah berapa kali penarikan atau withdrawal menjadi $\frac{Y}{W}-p$ dan brokerage cost akan menjadi $b \cdot \frac{Y}{W}-p$, atau brokerage cost mengalami penurunan.

c. Apabila $\frac{Y}{W}-p$ merupakan angka negatif, maka artinya peningkatan teknologi tidak mengurangi biaya atau brokerage cost, dan individu akan memilih 0 atau tidak melakukan trip ke bank atau tidak melakukan penarikan.

Dari persamaan di atas, dapat disimpulkan bahwa dengan adanya peningkatan tekno- 
logi, akan menyebabkan penurunan pada brokerage cost. Sehingga terdapat hubungan negatif antara peningkatan teknologi dan brokerage cost. Apabila dikembalikan pada persamaan permintaan uang untuk transaksi yang dijelaskan oleh Baumol (1952) dan Tobin (1956), maka:

$\frac{M^{t r}}{P}=\left(\frac{1}{2} b_{0}\right)^{1 / 2} y^{1 / 2} R^{-1 / 2}$

Atau dalam bentuk nominal:

$M^{t r}=\left(\frac{1}{2} b_{0} P\right)^{1 / 2} P \cdot y^{1 / 2} R^{-1 / 2}$

Dimana $\frac{\partial M^{t r}}{\partial b_{0}}>0$, maka terdapat hubungan positif antara money demand dengan brokerage cost. Artinya apabila terdapat penurunan biaya, maka terdapat penurunan money demand.

Kemudian Lippi dan Secchi (2009), menyampaikan teori mengenai adanya hubungan negatif antara teknologi dengan brokerage cost. Dari dua peneliti di atas, dapat disimpulkan mekanisme bagaimana transaction technology dapat mempengaruhi permintaan uang untuk transaksi (money demand for transaction). Berdasarkan persamaan yang disampaikan oleh Baumol (1952) dan Tobin (1956), money demand for transaction merupakan fungsi dari beberapa variabel yaitu:

$M^{t r}=f\left(b_{0}, y, P, R\right)$

Dengan penyempurnaan yang dilakukan oleh Lippi dan Secchi (2009), maka

$$
M^{t r}=f\left(b_{0}, y, P, R, \text { tech }\right)
$$

Dimana $\frac{\partial M^{t r}}{\partial_{\text {tech }}}<0$. Atau dapat disimpulkan bahwa dengan adanya technology, maka permintaan uang untuk transaksi akan menurun. Dari teori Baumol (1952) dan Tobin (1956) serta Lippi dan Secchi (2009), dapat digunakan untuk menganalisis hubungan atau interaksi dinamis antara inovasi finansial terhadap currency dan permintaan uang dalam arti sempit (M1).

Inovasi keuangan berbasis teknologi seperti ATM, transfer elektronik, kartu debet dan pembayaran online akan mengurangi brokerage cost dari menggunakan giro dan menurunkan permintaan uang untuk transaksi. Handa (2009) menyampaikan mengenai technical Innovation dan demand for monetary asset, bahwa dalam beberapa dekade terakhir terdapat sejumlah inovasi di sektor finansial antara lain yaitu pertama, penciptaan tipe baru dalam aset keuangan dan peningkatan likuiditas dari beberapa aset eksisting termasuk di dalamnya interest bearing asset demand deposits, dan checkable saving deposits, penjualan dan pembelian reksadana dan divestasinya ke giro dalam waktu singkat dan dengan biaya brokerage cost yang sangat kecil, telah menggeser (shift) transaction demand for currency, demand deposits, dan saving deposits.

Yang kedua adalah technical innovation dalam mekanisme menyimpan dan menarik uang seperti ATM, telephone dan computer based transfer, serta debit card, telah mengurangi brokerage cost dalam menggunakan deposits dibandingkan dengan menggunakan check sehingga menurunkan transaction demand. Ketiga dengan perkembangan smart card, yang menyimpan nominal uang (stored valued), nasabah dapat melakukan transfer ke pihak lain pada saat transaksi tanpa melibatkan third party yaitu Bank atau credit card company. Smart card juga merupakan bentuk elektronik dari uang tunai atau currency.

Keempat yaitu perkembangan digital card, dan payment system yang membutuhkan keberadaan Bank untuk melakukan verifikasi, otorisasi dan clear transaction menggunakan koneksi jaringan berguna karena terdapat histori transaksi yang digunakan sebagai pembukuan transaksi dan alasan keamanan. Kelima, perkembangan online payments, dimana payment dapat dilakukan dari rekening bank ke penerima pembayaran (payee), menyebabkan berkurangnya monetary dan non monetary brokerage costs dari menggunakan demand deposits dan mengurangi demand atau permintaan atas demand deposits.

\section{Pengembangan Hipotesis}

Beberapa penelitian empiris terdahulu juga telah dilakukan untuk mengetahui peran inovasi keuangan dalam mempengaruhi permintaan uang. Baba et al. (1992) 
menyatakan bahwa learning curve sebagai proksi untuk adaptasi instrumen keuangan baru sebagai faktor yang mempengaruhi permintaan untuk uang, sementara Arrau et al. (1995) menggunakan random walk term dalam penelitiannya untuk mengetahui pengaruh inovasi finansial. Bordo dan Jonung (1987) menggunakan currrency ratio sebagai ukuran inovasi keuangan, Lieberman (1977) menggunakan trend waktu linier dalam fungsi permintaan uang untuk menghitung peningkatan kemampuan untuk mengelola uang. Cho dan Miles (2007) juga menyimpulkan bahwa inovasi keuangan adalah salah satu faktor yang mempengaruhi permintaan uang.

Penelitian mengenai hubungan antara inovasi finansial dengan permintaan uang dan output dilakukan oleh Akhand dan Milbourne (1986) yang pertama kali melakukan penelitian mengenai kartu sebagai alternatif pembayaran pada kerangka money demand, dan menyimpulkan bahwa penggunaan kartu membuat seseorang memegang uang tunai lebih sedikit, dan meningkatkan kepemilikan akan bonds dalam model Baumol Tobin. Kemudian Mulligan dan Sala-i-Martin (1992) meneliti, dari penelitian ditemukan adanya perbedaan dalam kecepatan difusi dari teknologi finansial di setiap prefectures di jepang dan secara umum area dengan populasi tinggi dan penduduk lebih kaya, difusi teknologi finansialnya lebih cepat dan terjadi pada tahap awal, hal tersebut dikarenakan biaya transaksi yang lebih rendah. Peneliti lain yaitu Alvarez dan Lippi (2009) meneruskan analisis dengan menggunakan Baumol-Tobin model, dan menyimpulkan bahwa terdapat hubungan negatif antara liquid money berupa cash dengan financial development pada saat suku bunga nominal dari deposits hampir mencapai nol, yang sesuai dengan kondisi Jepang selama dua dekade terakhir.

Pada beberapa penelitian, untuk variabel inovasi finansial, beberapa ukuran sudah menjadi proxy, antara lain menurut Mulligan dan Sala-i-Martin (1992) proxy yang diguna- kan adalah kepadatan penduduk, kemudian Fujiki dan Mulligan (1996) menggunakan rasio dari industri primer terhadap produk netto dari masing-masing prefecture di jepang sebagai tambahan proxy ukuran kepadatan penduduk, lalu Lippi dan Secchi (2009) menggunakan proxy yaitu informasi dari ketersediaan kartu ATM dan cabang dari Bank (rekening bank) yang menunjukkan hubungan negatif dan signifikan antara uang tunai yang dipegang oleh penduduk Italia dengan kemajuan dari teknologi finansial. Hubungan negatif antara inovasi finansial dan permintaan uang juga dilaporkan oleh Lieberman (1977), Daniels dan Murphy (1994), dan Attanasio et al. (2002), dengan menggunakan ATM dan data keuangan lainnya sebagai proxy inovasi finansial. Hal yang sama juga dilakukan oleh Fischer (2007) menggunakan jumlah ATM sebagai proxy inovasi finansial di Swiss, namun dilaporkan bahwa variabel tersebut memiliki hubungan yang negatif dan tidak signifikan berkorelasi dengan money (terjadi di empat dari 6 kasus).

Duca dan Whitesell (1995) juga melakukan penelitian mengenai pengaruh credit card terhadap money demand dan menyimpulkan bahwa kepemilikan kartu kredit berkaitan dengan transactions deposits yang lebih rendah.

Kemudian Columba (2009) melakukan analisa mengenai pengaruh dari inovasi transaction technology terhadap permintaan uang dalam arti sempit (narrow money) dengan menggunakan data disagregasi pada level provinsi di Italia. Dalam penelitian tersebut dilakukan evaluasi pengaruh difusi dari ATM dan POS (Point of Sale) terhadap demand for currency dan permintaan akan M1, disimpulkan bahwa transaction technology memiliki pengaruh negatif terhadap permintaan uang tunai, sementara pengaruh terhadap M1 adalah positif. Lalu Yazgan dan Yilmazkuday (2009) melakukan analisa pengaruh dari credit card dan debet card terhadap currency dengan menggunakan data bulanan dari tahun 2002 sampai dengan 2006 di Turki, menyimpulkan bahwa 
peningkatan penggunaan kartu kredit dan kartu debet akan menyebabkan penurunan pada permintaan akan uang tunai. Dengan menggunakan data agregat, Rinaldi (2001) melakukan analisa mengenai pengaruh dari credit card, debet card, payment card terminal dan ATM terhadap peredaran uang tunai di Belgia menggunakan data time series, yang menghasilkan kesimpulan bahwa jumlah payment card terminal dan ATM memiliki pengaruh negatif terhadap sirkulasi dari peredaran uang tunai. Sementara itu kontribusi dari Stix (2004) fokus terhadap pengaruh dari teknologi pembayaran dan penarikan uang terhadap permintaan akan uang tunai. Penelitian tersebut menghasilkan kesimpulan bahwa penggunaan debit card secara signifikan mempengaruhi demand for cash.

Penelitian yang dilakukan Nagayasu (2012) melakukan pengujian ulang terhadap proxy yang digunakan dalam studi sebelumnya, serta menggunakan tambahan proxy dan data baru untuk merepresentasikan efek dari financial innovation yang belum pernah dilakukan sebelumnya dimana terdapat proxy spesifik yang hanya dapat diimplemen- tasikan di Jepang, yaitu ATM di seven eleven dan ATM yang berada di Post Office. Penelitian ini dilakukan menggunakan metode Panel Cointegration dengan data demand deposits, data GDP, jumlah cabang, jumlah kantor pos dan jumlah cabang Seven Eleven sampai dengan level prefectures di Jepang selama 15 tahun, yang memberikan hasil reliable jika dibandingkan dengan hanya menggunakan data aggregate atau nasional dan metode time series. Sebagai kesimpulan penelitian adalah inovasi finansial cenderung mengurangi demand deposits.

Dengan menggunakan data pada level bank, Carbo-Valverde dan RodriguezFernandez (2014) melakukan analisa bagaimana transaksi ATM dan POS mempengaruhi demand for money. Dari penelitian tersebut disimpulkan bahwa secara signifikan, transaksi ATM memiliki pengaruh positif terhadap demand for money dan transaksi POS memiliki pengaruh negatif terhadap demand for money. Pengaruh negatif dari transaksi POS tersebut mengeliminir pengaruh positif dari transaksi ATM. David et al. (2016) dalam penelitiannya mengenai pengaruh kartu debet terhadap permintaan uang tunai dengan menggunakan data mikro, menyimpulkan bahwa pengaruh negatif dari payment service (jasa pembayaran) terhadap permintaan uang tunai mendominasi pengaruh positif dari jasa penarikan uang tunai yang secara keseluruhan menghasilkan pengaruh negatif dari kartu debet terhadap permintaan uang tunai.

Oyelami dan Yinusa (2013) dalam studinya mengenai implikasi dari alternatif sistem pembayaran terhadap permintaan uang tunai dan kebijakan moneter di Nigeria dengan menggunakan alternatif sistem pembayaran berupa debit card, web atau internet banking, Point of Sales (POS) dan mobile money, dengan periode penelitian dari tahun 2008 sampai dengan tahun 2010. Dari hasil penelitian disimpulkan bahwa permintaan uang tunai menunjukkan respon negatif terhadap perkembangan mobile money dan internet banking, namun menunjukkan respon positif terhadap perkembangan debit card dan point of sales (POS) selama periode penelitian. Hasil tersebut menunjukkan bahwa internet banking dan mobile money merupakan subtitusi dari currency sedangkan debit card (ATM) dan POS merupakan pelengkap dari uang tunai, karena debit card (ATM) digunakan mayoritas untuk tujuan penarikan uang yang pada akhirnya akan menambah volume uang tunai dalam sirkulasi uang. Penelitian yang terbaru yang dilakukan oleh Aliha (2017) meneliti mengenai pengaruh inovasi finansial terhadap permintaan uang di Malaysia dengan menggunakan tiga kategori yaitu kategori pertama adalah payment instrument yaitu kartu kredit, kartu debet, charge card, dan e-money, kategori kedua adalah payment system yang terdiri dari transaksi Rentas, Interbank Giro, FPX dan direct debit, serta kategori yang ketiga adalah payment channels yaitu transaksi ATM, transaksi mobile banking dan transaksi internet banking. 
Hasil penelitiannya adalah untuk payment instrument, debit card berpengaruh negatif terhadap permintaan uang, kemudian untuk payment system, interbank Giro berpengaruh negatif terhadap permintaan uang, dan untuk proxy payment channels, mobile banking dan internet banking berpengaruh negatif terhadap permintaan uang. Kemudian Shiva dan Durai (2017) melakukan penelitian mengenai pengaruh kartu kredit dan kartu debet terhadap currency yang menyimpulkan bahwa penggunaan kartu kredit menurunkan permintaan currency.

Untuk kasus di Indonesia, terdapat beberapa peneliti yang melakukan penelitian mengenai dampak inovasi finansial terhadap permintaan uang dan juga terhadap kebijakan moneter. Pramono et al. (2006) dalam penelitiannya mengenai dampak pembayaran non tunai dengan proxy Alat Pembayaran Menggunakan Kartu (APMK) yaitu ATM, kartu debet dan kartu kredit, terhadap perekonomian dan kebijakan moneter, menarik kesimpulan bahwa semakin besar jumlah pembayaran non tunai, maka akan mengurangi permintaan uang dan akhirnya memiliki pengaruh terhadap kebijakan moneter. Sedangkan Sahabat (2009) melakukan penelitian mengenai pengaruh inovasi pembayaran (dengan proxy ATM, Kartu debet, Kartu Kredit, Transaksi kliring dan RTGS) terhadap permintaan uang dengan hasil inovasi sistem pembayaran memiliki hubungan jangka panjang yang negatif dengan permintaan uang. Syarifuddin et al. (2009) melakukan penelitian mengenai dampak peningkatan pembayaran non tunai terhadap perekonomian dan implikasinya terhadap pengendalian moneter di Indonesia, menyimpulkan bahwa pembayaran non tunai menurunkan biaya transaksi dan meningkatkan efisiensi dalam perekonomian. Dengan menggunakan structural cointegrating VAR dengan periode penelitian tahun 2000 sampai 2006, dilakukan pengujian dampak peningkatan pembayaran non tunai yang hasilnya adalah terdapat penurunan cash holding, meningkatkan money stock yaitu M1 dan M2, dan menyebabkan pertumbuhan GDP, namun hanya memiliki sedikit dampak pada penurunan harga.

Berdasarkan teori yang disampaikan oleh Baumol (1952) dan Tobin (1956) serta teori yang disampaikan oleh Lippi dan Secchi (2009) serta penelitian terdahulu, hipotesis dari penelitian ini adalah bahwa perkembangan inovasi finansial sistem pembayaran akan mengurangi permintaan currency serta permintaan uang dalam arti sempitataunarrow money (M1).

\section{METODE PENELITIAN \\ Sumber Data}

Data mengenai biaya transaksi atau brokerage cost untuk masing-masing jenis simpanan dan jenis inovasi finansial tidak tersedia, oleh karena itu data yang digunakan dalam penelitian ini adalah data inovasi sistem pembayaran, data GDP riil, indeks harga konsumen, data permintaan uang, data Indeks Harga Saham Gabungan data suku bunga bank sentral dan suku bunga deposito dalam 11 tahun terakhir (2007-2017). Sedangkan pertimbangan pemilihan jangka waktu penelitian selama 11 tahun terakhir (2007-2017) karena data inovasi sistem pembayaran yaitu electronic money baru tersedia pada tahun 2007. Data dan sumber data dalam penelitian adalah data inflasi dengan menggunakan proxy indeks harga konsumen yang berasal dari Badan Pusat Statistik (BPS), data PDBriil (dalam miliar rupiah) adalah PDB menurut harga konstan berasal dari Badan Pusat Statistik (BPS), data suku bunga Bank Sentral (BI rate) dan Suku bunga deposito 1 bulan (dalam \%) berasal dari Statistik Ekonomi Keuangan Indonesia (SEKI) Bank Indonesia, data base narrow money (M1), dan currency (dalam miliar rupiah) diperoleh dari Statistik Ekonomi Keuangan Indonesia (SEKI) Bank Indonesia, data inovasi finansial sistem pembayaran yaitu nilai transaksi kartu debet atau ATM, kartu kredit, RTGS, Kliring dan electronic money (dalam miliar rupiah) 
diperoleh dari Statistik Sistem Pembayaran Bank Indonesia, dan data Indeks Harga Saham Gabungan (IHSG) diperoleh dari Bursa Efek Indonesia.

Langkah-langkah analisis data adalah Uji Stasioneritas variabel dengan menggunakan Augmented Dickey Fuller (ADF) test dan Phillips Perron test, penentuan lag optimal, uji stabilitas model, uji kointegrasi. Adapun metode yang akan digunakan dalam penelitian ini adalah metode estimasi dengan menggunakan Vector Error Correnction Mechanism (VECM) dengan melakukan pengujian pada beberapa proxy atau indikator yang digunakan untuk dapat mengukur inovasi finansial sistem pembayaran. Masalah ketidakstasioneran data dapat diatasi dengan metode VECM jika uji kointegrasi terpenuhi.

\section{Definisi Operasional Variabel}

Variabel dependen yang digunakan dalam penelitian ini yaitu variabel currency dan permintaan uang dalam arti sempit (M1), adalah data bulanan jumlah currency dan M1 selama 11 tahun terakhir (2007-2017) dalam miliar rupiah. Kemudian variabel independennya adalah variabel inovasi finansial sistem pembayaran yang meliputi RTGS, Kliring, ATM atau Kartu debet, Kartu Kredit dan e-money dalam satuan miliar rupiah. Variabel inovasi finansial sistem pembayaran tersebut menggunakan beberapa metode pengukuran atau proxy. Variabel lainnya adalah nilai GDP riil adalah GDP berdasarkan harga konstan dalam miliar rupiah. Data PDB triwulanan diinterpolasi menjadi data bulanan dengan menggunakan metode quadratic-match sum (with sum observation). Variabel Suku bunga Bank Sentral yang dimaksud dalam penelitian ini adalah data bulanan tingkat suku bunga acuan yang ditetapkan oleh Bank Indonesia (dalam persentase). Variabel Suku bunga deposito yang dimaksud dalam penelitian ini adalah data bulanan suku bunga deposito dengan jangka waktu 1 (satu) bulan dari bank umum (dalam persentase). Variabel IHSG yang dimaksud dalam penelitian ini adalah data bulanan Indeks Harga Saham Gabungan (IHSG), yang merupakan opportunity cost of money.

\section{Model Empiris}

Model yang digunakan untuk melakukan estimasi pengaruh inovasi finansial sistem pembayaran terhadap permintaan uang mengikuti penelitian yang dilakukan oleh Rinaldi (2001), Columba (2009), dan Sahabat (2009) dengan beberapa penambahan variabel yang digunakan, yang dapat dituliskan sebagai berikut:

1) Interaksi dinamis antara inovasi finansial terhadap currency

$\Delta Y_{t}=\rho_{0}+\sum_{i=1}^{n} \Gamma \Delta Y_{t-i}+\gamma_{1} E C T_{t-i}+\varepsilon_{t}$

Dimana

$\Delta Y_{t}$ : matriks first difference

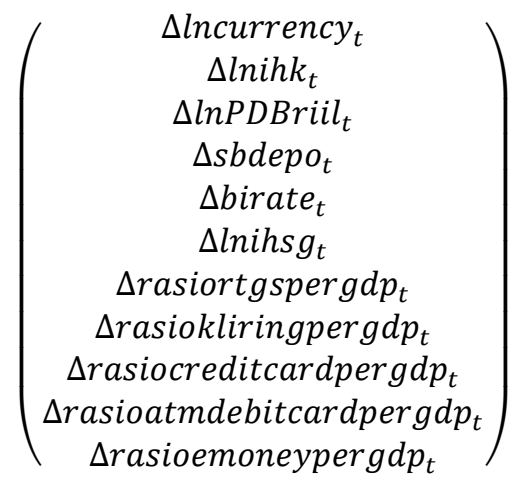

Matriks $\Gamma$ adalah sebagai berikut:

$\left(\begin{array}{lllllllllll}\sigma_{11} & \sigma_{12} & \sigma_{13} & \sigma_{14} & \sigma_{15} & \sigma_{16} & \sigma_{17} & \sigma_{18} & \sigma_{19} & \phi_{11} & \phi_{12} \\ \sigma_{21} & \sigma_{22} & \sigma_{23} & \sigma_{24} & \sigma_{25} & \sigma_{26} & \sigma_{27} & \sigma_{28} & \sigma_{29} & \phi_{21} & \phi_{22} \\ \sigma_{31} & \sigma_{32} & \sigma_{33} & \sigma_{34} & \sigma_{35} & \sigma_{36} & \sigma_{37} & \sigma_{38} & \sigma_{39} & \phi_{31} & \phi_{32} \\ \sigma_{41} & \sigma_{42} & \sigma_{43} & \sigma_{44} & \sigma_{45} & \sigma_{46} & \sigma_{47} & \sigma_{48} & \sigma_{49} & \phi_{41} & \phi_{42} \\ \sigma_{51} & \sigma_{52} & \sigma_{53} & \sigma_{54} & \sigma_{55} & \sigma_{56} & \sigma_{57} & \sigma_{58} & \sigma_{59} & \phi_{51} & \phi_{52} \\ \sigma_{61} & \sigma_{62} & \sigma_{63} & \sigma_{64} & \sigma_{65} & \sigma_{66} & \sigma_{67} & \sigma_{68} & \sigma_{69} & \phi_{61} & \phi_{62} \\ \sigma_{71} & \sigma_{72} & \sigma_{73} & \sigma_{74} & \sigma_{75} & \sigma_{76} & \sigma_{77} & \sigma_{78} & \sigma_{79} & \phi_{71} & \phi_{72} \\ \sigma_{81} & \sigma_{82} & \sigma_{83} & \sigma_{84} & \sigma_{85} & \sigma_{86} & \sigma_{87} & \sigma_{88} & \sigma_{89} & \phi_{81} & \phi_{82} \\ \sigma_{91} & \sigma_{92} & \sigma_{93} & \sigma_{94} & \sigma_{95} & \sigma_{96} & \sigma_{97} & \sigma_{98} & \sigma_{99} & \phi_{91} & \phi_{92} \\ \sigma_{101} & \sigma_{102} & \sigma_{103} & \sigma_{104} & \sigma_{105} & \sigma_{106} & \sigma_{107} & \sigma_{108} & \sigma_{109} & \phi_{101} & \phi_{102} \\ \sigma_{111} & \sigma_{112} & \sigma_{113} & \sigma_{114} & \sigma_{115} & \sigma_{116} & \sigma_{117} & \sigma_{118} & \sigma_{119} & \phi_{111} & \phi_{112}\end{array}\right)$

$\rho_{0}$ adalah vector konstanta untuk masingmasing variabel yang telah disebutkan di atas.

Adapun matriks $\Delta Y_{t-i}$ adalah sebagai berikut: 


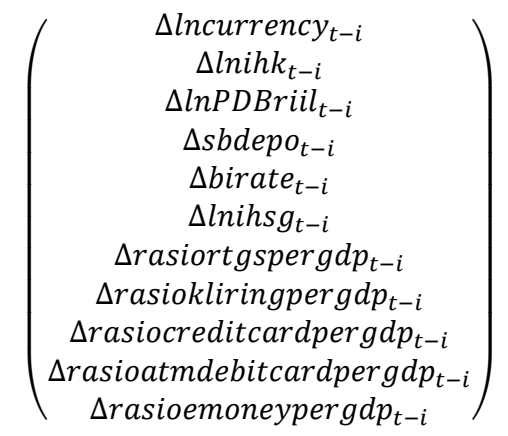

2) Interaksi dinamis antara inovasi finansial terhadap $M 1$

$\Delta Y_{t}=\beta_{0}+\sum_{i=1}^{n} \Gamma \Delta Y_{t-i}+\gamma_{1} E C T_{t-i}+\varepsilon_{t}$

Dimana

$\Delta Y_{t}$ : bentuk matriks first difference

$$
\left(\begin{array}{c}
\Delta \text { lnM }_{t} \\
\Delta \text { lninfl }_{t} \\
\Delta \text { lnPDBril }_{t} \\
\Delta \text { sbdepo }_{t} \\
\Delta \text { birate }_{t} \\
\Delta \text { lnihs }_{t} \\
\Delta \text { lnrtgs }_{t} \\
\Delta \text { lnkliring }_{t} \\
\Delta \text { lncreditcard }_{t} \\
\Delta \text { lnatmdebitcard }_{t} \\
\Delta \text { lnemoney }_{t}
\end{array}\right)
$$

Matriks $\Gamma$ adalah sebagai berikut:

$\left(\begin{array}{lllllllllll}\beta_{11} & \beta_{12} & \beta_{13} & \beta_{14} & \beta_{15} & \beta_{16} & \beta_{17} & \beta_{18} & \beta_{19} & \rho_{11} & \rho_{12} \\ \beta_{21} & \beta_{22} & \beta_{23} & \beta_{24} & \beta_{25} & \beta_{26} & \beta_{27} & \beta_{28} & \beta_{29} & \rho_{21} & \rho_{22} \\ \beta_{31} & \beta_{32} & \beta_{33} & \beta_{34} & \beta_{35} & \beta_{36} & \beta_{37} & \beta_{38} & \beta_{39} & \rho_{31} & \rho_{32} \\ \beta_{41} & \beta_{42} & \beta_{43} & \beta_{44} & \beta_{45} & \beta_{46} & \beta_{47} & \beta_{48} & \beta_{49} & \rho_{41} & \rho_{42} \\ \beta_{51} & \beta_{52} & \beta_{53} & \beta_{54} & \beta_{55} & \beta_{56} & \beta_{57} & \beta_{58} & \beta_{59} & \rho_{51} & \rho_{52} \\ \beta_{61} & \beta_{62} & \beta_{63} & \beta_{64} & \beta_{65} & \beta_{66} & \beta_{67} & \beta_{68} & \beta_{69} & \rho_{61} & \rho_{62} \\ \beta_{71} & \beta_{72} & \beta_{73} & \beta_{74} & \beta_{75} & \beta_{76} & \beta_{77} & \beta_{78} & \beta_{79} & \rho_{71} & \rho_{72} \\ \beta_{81} & \beta_{82} & \beta_{83} & \beta_{84} & \beta_{85} & \beta_{86} & \beta_{87} & \beta_{88} & \beta_{89} & \rho_{81} & \rho_{82} \\ \beta_{91} & \beta_{92} & \beta_{93} & \beta_{94} & \beta_{95} & \beta_{96} & \beta_{97} & \beta_{98} & \beta_{99} & \rho_{91} & \rho_{92} \\ \beta_{101} & \beta_{102} & \beta_{103} & \beta_{104} & \beta_{105} & \beta_{106} & \beta_{107} & \beta_{108} & \beta_{109} & \rho_{101} & \rho_{102} \\ \beta_{111} & \beta_{112} & \beta_{113} & \beta_{114} & \beta_{115} & \beta_{116} & \beta_{117} & \beta_{118} & \beta_{119} & \rho_{111} & \rho_{112}\end{array}\right)$

$\beta_{0}$ adalah vector konstanta untuk masingmasing variabel yang telah disebutkan di atas.

Adapun matriks $\Delta Y_{t-i}$ adalah sebagai berikut:

$$
\left(\begin{array}{c}
\Delta \operatorname{lnM}_{t-i} \\
\Delta \operatorname{lnihk}_{t-i} \\
\Delta \ln _{\ln P B i i l_{t-i}} \\
\Delta \text { sbdepo }_{t-i} \\
\Delta \text { birate }_{t-i} \\
\Delta \text { lnihs }_{t-i} \\
\Delta \text { llnrtgs }_{t-i} \\
\Delta \text { lnkliring }_{t-i} \\
\Delta \text { lncreditcard }_{t-i} \\
\Delta \text { lnatmdebitcard }_{t-i} \\
\Delta \text { lnemoney }_{t-i}
\end{array}\right)
$$

$\sum_{i=1}^{n} \Gamma \Delta Y_{t-i}$ adalah matriks yang terdiri dari matriks parameter $(\Gamma)$ dan berupa matriks komponen variabel dalam bentuk lag dari first difference $\left(\Delta Y_{t-i}\right)$.

ECT adalah error correction term $\varepsilon_{t}$ adalah residual.

Variabel yang digunakan dalam bentuk logaritma adalah: In currency yaitu jumlah currency, In M1 adalah jumlah M1, In IHK adalah proxy untuk inflasi, $\ln$ PDB riil merupakan nilai PDB riil, dan ln IHSG adalah index harga saham gabungan. Lalu rasio RTGS per GDP, rasio kliring per GDP, rasio credit card per GDP, rasio ATM debit card per GDP serta rasio emoney per GDP adalah rasio untuk masing-masing inovasi finansial sistem pembayaran terhadap GDP yang digunakan sebagai salah satu proxy untuk pengukuran inovasi finansial sistem pembayaran.

Demikian juga halnya dengan ln RTGS, In kliring, In credit card, In ATM debit card serta $\ln$ emoney merupakan nilai transaksi dari inovasi finansial sistem pembayaran yaitu RTGS, kliring, kartu kredit, ATM atau kartu debet, dan electronic money.

Variabel dalam bentuk persentase yaitu sbdepo yaitu suku bunga deposito dan birate yaitu suku bunga bank sentral. Dengan digunakannya beberapa proxy dalam estimasi interaksi dinamis antara inovasi finansial sistem pembayaran dengan currency serta M1, maka variabel inovasi finansial sistem pembayaran akan tergantung pada proxy yang digunakan dalam proses estimasi. Matriks first difference juga akan tergantung dari proxy yang digunakan.

Untuk menjelaskan pengaruh perkembangan inovasi finansial sistem pembayaran terhadap currency, dan juga terhadap narrow money (M1), hipotesis yang diuji dalam penelitian ini adalah sebagai berikut :

1. Inovasi finansial menurunkan currency. $\sigma_{17}<0, \sigma_{18}<0, \sigma_{19}<0, \phi_{11}<0, \phi_{12}<0$

2. Inovasi finansial sistem pembayaran menurunkan permintaan uang dalam arti sempit (M1). 
$\beta_{17}<0, \beta{ }_{18}<0, \beta_{19}<0, \rho_{11}<0, \rho_{12}<0$

Beberapa proxy yang diestimasi yaitu nilai transaksi inovasi finansial sistem pembayaran yang mencakup RTGS, Kliring, Kartu kredit, ATM debit, dan e-money; Nilai transaksi inovasi finansial sistem pembayaran (tanpa kliring) yang mencakup RTGS, Kartu kredit, ATM debit, dan emoney; Total nilai transaksi seluruh inovasi finansial sistem pembayaran; Volume transaksi untuk RTGS, Kartu kredit, ATM debit, dan e-money; Rasio inovasi sistem pembayaran terhadap GDP yaitu rasio dari masing-masing inovasi finansial sistem pembayaran yaitu RTGS, Kartu kredit, ATM debit, dan e-money terhadap GDP; Rasio inovasi sistem pembayaran terhadap M1; dan rasio M2 terhadap M1.

\section{ANALISIS DAN PEMBAHASAN \\ Pengaruh Inovasi Finansial terhadap Narrow Money (M1) dengan Menggunakan Proxy Nilai Transaksi}

Dengan menggunakan Phillips Perron test, dapat disampaikan bahwa variabel stasioner di first difference atau Integrated degree 1 atau I (1), Lag optimal diperoleh pada saat saat lag 1 , sehingga lag yang digunakan dalam penelitian adalah 1 , didasarkan dari kriteria SC dimana pada lag 1 , nilai SC dan HQ mencapai nilai minimum. Dari hasil kointegrasi, terdapat tiga kointegrasi yang berarti bahwa antar variabel yang diteliti terdapat hubungan jangka panjang. Berdasarkan hasil pengujian roots of characteristic polinominal, dapat disimpulkan bahwa model tersebut stabil.

Tabel 1

Interaksi dinamis antara inovasi finansial menggunakan proxy nilai transaksi dengan M1

\begin{tabular}{lccc}
\hline \hline Cointegrating Eq: & CointEq1 & CointEq2 & CointEq3 \\
\hline LN M1(-1) & 1.000 & 0.000 & 0.000 \\
LN_IHK(-1) & 0.000 & 1.000 & 0.000 \\
LN PDB RIIL(-1) & 0.000 & 0.000 & 1.000 \\
SB_DEPO(-1) & 0.000 & -0.0049 & -0.010 \\
& & $(0.004)$ & $(0.004)$ \\
BI_RATE(-1) & & {$[-1.121]$} & {$[-2.309]$} \\
& $0.082^{* *}$ & 0.000 & 0.0236 \\
& $(0.014)$ & & $(0.007)$ \\
LNIHSG(-1) & {$[5.774]$} & & {$[3.457]$} \\
& $0.215^{* *}$ & 0.000 & 0.000 \\
LN RTGS(-1) & $(0.042)$ & & \\
& {$[5.122]$} & & -0.134 \\
& $-0.828^{* *}$ & 0.293 & $(0.071)$ \\
LN KLIRING(-1) & $(0.370)$ & $(0.127)$ & {$[-1.899]$} \\
& {$[-2.238]$} & {$[2.301]$} & -0.648 \\
& $-3.352^{* *}$ & 1.140 & $(0.119)$ \\
LN KARTU KREDIT (-1) & $(0.624)$ & $(0.214)$ & $-5.453]$ \\
& {$[-5.370]$} & {$[5.317]$} & -0.007 \\
LNATM atau & 0.192 & -0.635 & $(0.253)$ \\
KARTU DEBET(-1) & $(1.331)$ & $(0.457)$ & {$[-0.029]$} \\
& {$[0.144]$} & {$[-1.390]$} & 0.223 \\
& $1.715^{* *}$ & -0.894 & {$[0.074)$} \\
& $(0.390)$ & $(0.134)$ & {$[-6.001]$}
\end{tabular}




$\begin{array}{lccc}\text { LN EMONEY(-1) } & 0.051 & 0.007 & -0.001 \\ & (0.199) & (0.068) & (0.038) \\ & {[0.254]} & {[0.109]} & {[-0.032]} \\ \text { C } & 15.309 & -6.269 & -6.081\end{array}$

Catatan:

Standard errors dalam ( ) \& t-statistics dalam [ ].

Signifikansi pada taraf nyata $5 \%$ (t statistik $>1.96$ ). Koefisien dalam persamaan kointegrasi yang dicantumkan dalam tabel, diinterpretasikan sebagai opposite sign.

Sumber: Output hasil penelitian tahun 2018

Persamaan kointegrasi dapat ditulis sebagai berikut:

$$
\begin{aligned}
\text { Ln } \quad= & -0,082 \text { BIrate }_{t}-0,125 \ln \text { IHSG }_{t} \\
\text { M1 }_{t} & +0,828 \text { RTGS }_{t}+3,352 \ln \text { kliring }_{t} \\
& -0,192 \ln \text { kartu kredit } \\
& -1,715 \ln \\
& \text { ATM atau kartu debit }{ }_{t}- \\
& \text { 0,051ln emoney } \text { en }_{t}-15,309
\end{aligned}
$$

Adapun ECT dalam persamaan dlnM1 adalah $-0,158 * *$ dimana speed of adjustment yaitu selama 6,32 bulan.

Dari hasil estimasi di atas, dapat disimpulkan bahwa untuk M1, ATM atau kartu debet memiliki hubungan negatif dan signifikan terhadap M1 yaitu apabila terdapat peningkatan $1 \%$ pada ATM atau kartu debet maka akan menurunkan M1 sebesar $1,715 \%$. Artinya adalah bahwa peningkatan penggunaan ATM atau Kartu debet sebagai pengganti atau substitusi dari uang tunai mengurangi permintaan akan M1.

Namun, RTGS dan kliring secara signifikan meningkatkan M1 dengan interpretasi bahwa peningkatan $1 \%$ pada transaksi RTGS dan kliring akan berturut-turut meningkatkan M1 sebesar 0,828\% dan 3,352\%. Peningkatan M1 akibat dari peningkatan RTGS dan kliring mengindikasikan bahwa semakin tinggi transaksi RTGS dan kliring sehingga permintaan M1 menjadi meningkat.

Pengaruh Inovasi Finansial terhadap Fungsi Narrow Money (M1) dengan Menggunakan Proxy Total Nilai Transaksi

Analisis pengaruh inovasi finansial terhadap fungsi permintaan uang dengan menggunakan proxy nilai transaksi meng- gambarkan pengaruh dari total nilai transaksi inovasi finansial (RTGS, Kliring, ATM, Kartu kredit dan electronic money) terhadap permintaan uang dalam arti sempit (M1). Uji Stasioneritas: I (1), Lag: 1, Jumlah Persamaan kointegrasi: 1

\section{Tabel 2}

Hasil Interaksi dinamis antara inovasi finansial menggunakan proxy total nilai transaksi terhadap M1

\begin{tabular}{cc}
\hline \hline Cointegrating Eq: & CointEq1 \\
\hline LN M1(-1) & 1.000 \\
LN IHK(-1) & $1.620^{* *}$ \\
& $(0.274)$ \\
& {$[5.912]$} \\
LN PDB RIIL(-1) & $-3.943^{* *}$ \\
& $(0.287)$ \\
SB_DEPO(-1) & {$[-13.748]$} \\
& 0.001 \\
BI_RATE(-1) & $(0.011)$ \\
& {$[0.124]$} \\
LN IHSG(-1) & -0.002 \\
& $(0.010)$ \\
& {$[-0.192]$} \\
LN INOVSP(-1) & 0.004 \\
& $(0.044)$ \\
& {$[0.088]$} \\
C & 0.007 \\
\end{tabular}

Sumber: Output hasil penelitian tahun 2018

Persamaan kointegrasi dapat dituliskan sebagai berikut: 
$\mathrm{LnM1}_{\mathrm{t}}=-1,620 \ln \mathrm{IHK}_{\mathrm{t}}+3,943 \ln$ PDB riil $\mathrm{t}^{-}$ $0,001 \mathrm{SB}$ depo $_{\mathrm{t}}+0,002 \mathrm{BI}$ rate $_{\mathrm{t}}-$ 0,004 ln IHSG $_{t}-0,007$ ln inovsp $_{t}$ 31,634

Adapun ECT dalam persamaan dlnM1 adalah $-0,175^{* *}$ dimana speed of adjustment adalah 5,77 bulan.

Dari hasil estimasi dengan menggunakan VECM, dapat dilihat bahwa peningkatan inovasi finansial sistem pembayaran (RTGS, Kliring, ATM atau debit, Kartu kredit dan e-money) secara total, tidak signifikan mempengaruhi M1.
Pengaruh Inovasi Finansial terhadap Narrow Money (M1) dengan Menggunakan Proxy Nilai Transaksi Tanpa Kliring

Terkait dengan nilai transaksi tanpa menggunakan variable kliring, dilakukan dengan tujuan untuk mengetahui interaksi dinamis inovasi sistem pembayaran (yang terbaru) terhadap M1.

Pada estimasi berikut diasumsikan bahwa kliring merupakan inovasi sistem pembayaran yang masih menggunakan paper based, sehingga tidak dimasukkan sebagai variabel inovasi sistem pembayaran. Uji Stasioneritas: I (1), Lag: 1, Jumlah Persamaan kointegrasi: 3 .

Tabel 3

Hasil Interaksi dinamis antara inovasi finansial menggunakan proxy nilai transaksi (tanpa kliring) terhadap M1

\begin{tabular}{lccc}
\hline \multicolumn{1}{c}{ Cointegrating Eq: } & CointEq1 & CointEq2 & CointEq3 \\
\hline LN_IHK(-1) & 1.000 & 0.000 & 0.000 \\
LN PDB RIIL(-1) & 0.000 & 1.000 & 0.000 \\
LNM1(-1) & 0.000 & 0.000 & 1.000 \\
SB_DEPO(-1) & 0.000 & -0.008 & 0.000 \\
& & $(0.005)$ & \\
BI_RATE(-1) & & {$[-1.566]$} & \\
& 0.014 & 0.057 & 0.066 \\
& $(0.006)$ & $(0.044)$ & $(0.044)$ \\
LN IHSG(-1) & {$[2.274]$} & {$[1.310]$} & {$[1.486]$} \\
& 0.000 & 1.091 & $1.061^{* *}$ \\
& & $(0.133)$ & $(0.127)$ \\
LN RTGS(-1) & & {$[8.230]$} & {$[8.374]$} \\
& 0.0590 & -0.185 & -0.240 \\
& $(0.030)$ & $(0.208)$ & $(0.213)$ \\
LN ATM atau & {$[1.958]$} & {$[-0.889]$} & {$[-1.125]$} \\
KARTU DEBET(-1) & -0.100 & -1.056 & $-1.387^{* *}$ \\
& $(0.033)$ & $(0.228)$ & $(0.233)$ \\
LNKARTU & {$[-3.011]$} & {$[-4.640]$} & {$[-5.945]$} \\
KREDIT(-1) & -0.655 & 0.112 & 0.267 \\
& $(0.108)$ & $(0.766)$ & $(0.781)$ \\
LN EMONEY(-1) & {$[-6.075]$} & {$[0.147]$} & {$[0.342]$} \\
& 0.0542 & 0.053 & 0.008 \\
C & $(0.017)$ & $(0.120)$ & $(0.122)$ \\
& {$[3.214]$} & {$[0.441]$} & {$[0.069]$} \\
& 1.704 & -7.908 & -4.196 \\
\hline
\end{tabular}


Persamaan kointegrasi dapat dituliskan sebagai berikut:

Ln M1 $1_{t}=-0,066$ BI rate $-1,061 \ln$ IHSG $_{t}$

$+0,240$ ln RTGS $_{\mathrm{t}}+1,387 \mathrm{ln}$ ATM atau

kartu debit $-0,267$ ln kartu kredit $t_{t}$

$-0,008$ lne-money $+4,196$.

Adapun ECT dalam persamaan dlnM1 adalah $-0,520^{* *}$, dimana speed of adjustment adalah 1,92 bulan.

Dari hasil estimasi di atas, dapat disimpulkan bahwa untuk M1, ATMataukartu debet secara signifikan meningkatkan M1 dengan interpretasi bahwa peningkatan 1\% pada ATM debit akan meningkatkan M1 sebesar $1.387 \%$. Peningkatan M1 akibat dari peningkatan ATM atau debit dan kartu kredit mengindikasikan bahwa semakin tinggi transaksi ATM debit dan kartu kredit, membuat permintaan M1 menjadi meningkat.

Pengaruh Inovasi Finansial terhadap Narrow Money (M1) dengan Menggunakan Proxy Volume Transaksi

Proxy volume transaksi merupakan salah satu yang digunakan untuk melihat dari sisi volume transaksi, bagaimana interaksi dinamis inovasi finansial sistem pembayaran terhadap M1. Uji Stasioneritas: I (1), Lag: 1, Jumlah persamaan kointegrasi sebanyak 3 persamaan kointegrasi.

Tabel 4

Hasil Interaksi dinamis antara inovasi finansial menggunakan proxy volume transaksi terhadap M1

\begin{tabular}{lccc}
\hline \multicolumn{1}{c}{ Cointegrating Eq: } & CointEq1 & CointEq2 & CointEq3 \\
\hline LN M1(-1) & 1.000 & 0.000 & 0.000 \\
LN IHK(-1) & 0.000 & 1.000 & 0.000 \\
LN PDB RIIL(-1) & 0.000 & 0.000 & 1.000 \\
SB_DEPO(-1) & 0.000 & 0.0006 & -0.001 \\
& & $(0.002)$ & $(0.003)$ \\
BI_RATE(-1) & & {$[0.261]$} & {$[-0.366]$} \\
& $0.034^{* *}$ & -0.011 & 0.003 \\
LN IHSG(-1) & $(0.006)$ & $(0.003)$ & $(0.004)$ \\
& {$[6.063]$} & {$[-4.337]$} & {$[0.782]$} \\
LN RTGS VOL(-1) & -0.009 & 0.000 & 0.000 \\
& $(0.030)$ & & \\
LN KARTU KREDIT VOL(-1) & {$[-0.316]$} & & \\
& 0.011 & -0.005 & 0.003 \\
& $(0.018)$ & $(0.005)$ & $(0.008)$ \\
LN ATM DEBIT VOL(-1) & {$[0.580]$} & {$[-1.095]$} & {$[0.352]$} \\
& 0.020 & -0.507 & -0.193 \\
LN EMONEY VOL (-1) & {$[0.11261)$} & $(0.035)$ & $(0.056)$ \\
& $0.18014]$ & {$[-14.703]$} & {$[-3.347]$} \\
C & $-0.763^{* *}$ & -0.156 & -0.277 \\
& $(0.053)$ & $(0.012)$ & $(0.020)$ \\
& {$[-14.416]$} & {$[-13.136]$} & {$[-14.057]$} \\
& $0.025^{* *}$ & 0.0150 & 0.0154 \\
& $(0.012)$ & $(0.003)$ & $(0.006)$ \\
& {$[2.042]$} & {$[4.641]$} & {$[2.799]$} \\
& 0.184 & 6.789 & -5.100 \\
\hline
\end{tabular}

Sumber: Output hasil penelitian tahun 2018 
Persamaan kointegrasi dapat dituliskan sebagai berikut:

Ln M1 $1_{t}=-0,034$ BI rate $-0,0091$ IHSG $_{t}-0,011$ RTGSvol $_{t}$ - 0,020ln kartu kredit vol $_{t}+0,763 \ln$ ATM debit vol $-0,025 \ln$ emoney vol $_{t}-0,184$

Adapun ECT dalam persamaan dlnM1 adalah $-0,361^{* *}$ dimana speed of adjustment adalah 2,77 bulan.

Dari hasil estimasi di atas, dapat disimpulkan bahwa untuk M1, electronic money memiliki hubungan negatif dan signifikan terhadap M1 yaitu apabila terdapat peningkatan $1 \%$ pada e-money, maka akan menurunkan M1 sebesar $0.025 \%$. Hal ini memiliki implikasi bahwa peningkatan penggunaan electronic money sebagai substitusi dari uang tunai menurunkan permintaan akan M1. Sedangkan, ATM atau kartu debet signifikan meningkatkan M1 dengan interpretasi bahwa peningkatan $1 \%$ pada
ATM debit akan meningkatkan M1 sebesar 0,763\%. Peningkatan M1 akibat dari peningkatan ATM atau kartu debet mengindikasikan bahwa semakin tinggi volume transaksi ATM debit, sehingga permintaan M1 menjadi meningkat.

\section{Pengaruh Inovasi Finansial terhadap} Narrow Money (M1) dengan Menggunakan Proxy Rasio Inovasi Finansial terhadap GDP

Analisis dengan menggunakan proxy rasio inovasi finansial sistem pembayaran terhadap GDP menggambarkan besarnya rasio inovasi finansial sistem pembayaran yaitu RTGS, Kartu kredit, ATM debit dan electronic money terhadap GDP. Artinya adalah berapa porsi atau komposisi dari GDP yang transaksinya dilakukan menggunakan inovasi finansial sistem pembayaran.

Uji Stasioneritas: I (1), Lag: 1, Jumlah Persamaan kointegrasi: 2.

Tabel 5

Hasil Interaksi dinamis antara inovasi finansial menggunakan proxy rasio inovasi finansial Sistem Pembayaran terhadap GDP

\begin{tabular}{lcc}
\hline \multicolumn{1}{c}{ Cointegrating Eq: } & CointEq1 & CointEq2 \\
\hline LN M1(-1) & 1.000 & 0.000 \\
INFLASI_YOY(-1) & 0.000 & 1.000 \\
LN PDB RIIL(-1) & $-2.969^{* * *}$ & 1537.566 \\
& $(0.213)$ & $(180.505)$ \\
& {$[-13.915]$} & {$[8.518]$} \\
SB_DEPO(-1) & 0.000 & 24.428 \\
& & $(4.882)$ \\
BI_RATE(-1) & & {$[5.004]$} \\
& $0.019^{* * *}$ & 0.000 \\
LN IHSG(-1) & $(0.006)$ & \\
& {$[3.060]$} & \\
& 0.043 & 0.000 \\
RTGS PER GDP RIIL(-1) & $(0.027)$ & \\
& {$[1.579]$} & \\
& -0.00006 & 0.008 \\
& $(3.7 \mathrm{E}-05)$ & $(0.032)$ \\
& {$[-1.660]$} & {$[0.245]$} \\
& $0.152^{* * *}$ & -289.831
\end{tabular}




\begin{tabular}{lcc} 
KARTU KREDIT PER GDP(- & $(0.038)$ & $(34.284)$ \\
$1)$ & {$[4.038]$} & {$[-8.454]$} \\
ATM DEBIT PER GDP(-1) & 0.002 & -12.994 \\
& $(0.002)$ & $(2.077)$ \\
EMONEY PER GDP(-1) & {$[0.731]$} & {$[-6.257]$} \\
& $1.382^{* * *}$ & -829.552 \\
C & $(0.614)$ & $(508.921)$ \\
\hline
\end{tabular}

Sumber: Output hasil penelitian tahun 2018

Persamaan kointegrasi dapat dituliskan sebagai berikut:

Ln M1 $1_{t}=2,969 \ln$ PDB riil $t_{t}-0,019$ BI rate $_{t}-$ 0,043 ln IHSG $_{t}+0,00006$ RTGS per $\mathrm{GDP}_{\mathrm{t}}-0,152 \ln$ kartu kredit per gdp $_{\mathrm{t}}-0,002 \ln$ ATM debit per GDP ${ }_{\mathrm{t}}$ $-1,382$ ln emoney per $\mathrm{GDP}_{t}-25,339$

Adapun ECT dalam persamaan dlnM1 adalah $-0,348^{* *}$ dimana speed of adjustment adalah 2,87 bulan.

Dari hasil estimasi di atas, dapat disimpulkan bahwa kartu kredit dan electronic money memiliki hubungan negatif terhadap M1 yaitu jika terdapat peningkatan 1\% pada rasio Kartu kredit, dan electronic money terhadap GDP, maka akan signifikan menurunkan M1, berturut-turut sebesar $0,152 \%$ dan $1,382 \%$.

Pengaruh Inovasi Finansial terhadap Narrow Money (M1) dengan Menggunakan Proxy Rasio Inovasi Sistem Pembayaran atau M1

Analisis dengan menggunakan proxy rasio inovasi finansial sistem pembayaran terhadap M1 menggambarkan besarnya rasio inovasi finansial sistem pembayaran yaitu RTGS, Kartu kredit, ATM debit dan emoney terhadap M1.

Artinya adalah berapa porsi atau komposisi dari M1 yang transaksinya dilakukan menggunakan inovasi finansial sistem pembayaran. Hasil uji Stasioneritas: I (1), Lag: 1, Jumlah Persamaan kointegrasi: 1.

Tabel 6

Hasil Interaksi dinamis antara inovasi finansial menggunakan proxy rasio Inovasi Finansial Sistem Pembayaran terhadap M1

\begin{tabular}{lcc}
\hline \multicolumn{1}{c}{ Cointegrating Eq: } & CointEq1 & CointEq2 \\
\hline LN M1(-1) & 1.000 & 0.000 \\
INFLASI(-1) & 0.000 & 1.000 \\
LN PDB RIIL(-1) & $-2.498^{* *}$ & 115.248 \\
& $(0.139)$ & $(31.085)$ \\
& {$[-17.956]$} & {$[3.708]$} \\
SB_DEPO(-1) & 0.000 & 12.905 \\
& & $(1.965)$ \\
& & {$[6.567]$} \\
BI_RATE(-1) & 0.011 & 0.000 \\
& $(0.009)$ & \\
LN IHSG(-1) & {$[1.295]$} & \\
& 0.028 & 0.000 \\
& $(0.038)$ &
\end{tabular}




\begin{tabular}{lcc} 
& {$[0.756]$} & \\
RTGS PER M1(-1) & -0.000045 & -0.010 \\
& $(3.5 \mathrm{E}-05)$ & $(0.010)$ \\
KARTU KREDIT PER M1(-1) & {$[-1.310]$} & {$[-1.036]$} \\
& $0.121^{* *}$ & -97.105 \\
ATM DEBIT CARD PER M1(-1) & $(0.036)$ & $(11.763)$ \\
& {$[3.382]$} & {$[-8.255]$} \\
EMONEY PER M1(-1) & 0.004 & -6.676 \\
& $(0.003)$ & $(0.820)$ \\
C & {$[1.365]$} & {$[-8.146]$} \\
& 1.497 & -403.769 \\
& $(0.843)$ & $(229.853)$ \\
\hline
\end{tabular}

Sumber: Output hasil penelitian tahun 2018

Persamaan kointegrasi dapat dituliskan sebagai berikut:

$\mathrm{LnM1}_{\mathrm{t}}=2.482 \ln$ PDB riil $\mathrm{t}_{\mathrm{t}}-0.011 \mathrm{BI}_{\text {rate }_{\mathrm{t}}}{ }^{-}$ $0.028 \ln$ IHSG $_{t}+0.000045$ RTGS per $\mathrm{M}_{\mathrm{t}}-0.121$ Kartu kredit perM1 10.004 ATM debit card perM1 $1_{\mathrm{t}-\mathrm{i}}-1.497$ emoney per $\mathrm{m} 1_{\mathrm{t}-\mathrm{i}}{ }^{-}$ 19.267

Adapun ECT dalam persamaan dlnM1 sebesar $-0.286^{* *}$, dimana speed of adjustment adalah 3.49 bulan.

Dari hasil estimasi di atas, dapat disimpulkan bahwa untuk M1, Kartu kredit memiliki hubungan negatif dan signifikan terhadap M1 yaitu apabila terdapat peningkatan $1 \%$ pada rasio Kartu kredit terhadap M1, maka akan menurunkan M1 sebesar $0.121 \%$. Hal ini memiliki implikasi bahwa peningkatan penggunaan kartu kredit sebagai substitusi dari uang tunai menurunkan permintaan akan M1.

Pengaruh Inovasi Finansial terhadap Narrow Money (M1) dengan Menggunakan Proxy Rasio M2 per M1

Analisis dengan menggunakan rasio M2 terhadap M1 dengan pertimbangan bahwa substitusi uang yang timbul akibat penggunaan inovasi finansial sistem pembayaran lebih tercermin pada M2 daripada di M1. Dan dengan perkembangan inovasi finan- sial, individu berpindah dari liquid assets (M1) ke less liquid assets yaitu M2. Sehingga inovasi finansial sistem pembayaran juga dapat dilihat dari rasio M2 terhadap M1. Uji Stasioneritas: I (1), Lag: 1, Jumlah Persamaan kointegrasi: 1

Tabel 7

Hasil Interaksi dinamis antara inovasi finansial menggunakan proxy rasio $\mathrm{M} 2$ terhadap M1

\begin{tabular}{lc}
\hline \hline Cointegrating Eq: & CointEq1 \\
\hline LN M1(-1) & 1.000 \\
INFLASI_YOY(-1) & -0.006 \\
& $(0.004)$ \\
& {$[-1.635]$} \\
LN PDB RIIL(-1) & $-2.184^{* *}$ \\
& $(0.075)$ \\
SB_DEPO(-1) & {$[-29.083]$} \\
BI_RATE(-1) & 0.000 \\
& 0.0125 \\
& $(0.008)$ \\
LN IHSG(-1) & {$[1.651]$} \\
& -0.061 \\
& $(0.031)$ \\
M2 per M1(-1) & {$[-1.978]$} \\
& 0.0664 \\
C & $(0.040)$ \\
\hline
\end{tabular}

Sumber: Output hasil penelitian tahun 2018 
Persamaan kointegrasi dapat dituliskan sebagai berikut:

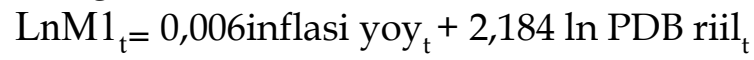
-0.0125 SB depo $o_{t}+0.061$ ln IHSG $_{t}$ $-0,066 \mathrm{M} 2$ per $\mathrm{M} 1_{t}-15,905$

Adapun ECT dalam persamaan dlnM1:

$-0,257^{* *}$, dimana speed of adjustment adalah 3,89 bulan.

Dari hasil estimasi dengan menggunakan VECM, dapat dilihat bahwa dengan menggunakan rasio M2 terhadap M1, inovasi finansial tidak signifikan mempengaruhi M1.

Pengaruh Inovasi Finansial Sistem Pembayaran Terhadap Currency

Hasil penelitian untuk pengaruh inovasi finansial sistem pembayaran terhadap currency dapat dijelaskan dari Tabel 4.8 sebagai berikut:

\section{Tabel 8}

Hasil Interaksi dinamis antara inovasi finansial menggunakan beberapa proxy

a. Total transaksi

\begin{tabular}{lc}
\hline \multicolumn{1}{c}{ Cointegrating Eq: } & CointEq1 \\
\hline LN CURRENCY(-1) & 1.000 \\
LN IHK(-1) & 0.000 \\
& -2.128 \\
LN PDB RIIL(-1) & $(0.132)$ \\
& {$[-16.122]$} \\
SB_DEPO(-1) & 0.002 \\
& $(0.008)$ \\
BI_RATE(-1) & $0.283]$ \\
& 0.000 \\
LN IHSG(-1) & -0.060 \\
& $(0.065)$ \\
LN INOVSPNC(-1) & {$[-0.916]$} \\
& 0.005 \\
C & $(0.048)$ \\
& {$[0.118]$} \\
\end{tabular}

b. Rasio M2 terhadap M1

\begin{tabular}{lc}
\hline \hline Cointegrating Eq: & CointEq1 \\
\hline LN CURRENCY(-1) & 1.000
\end{tabular}

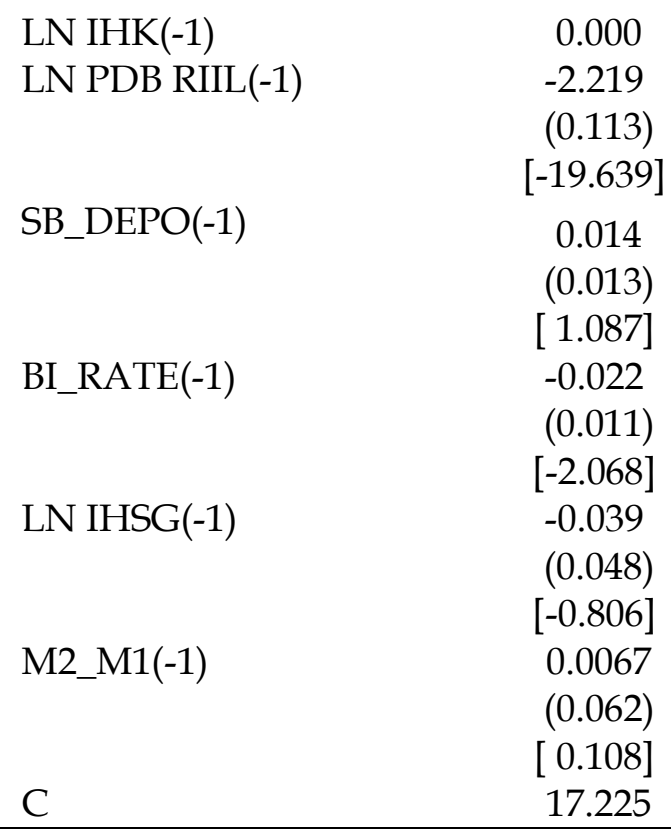

c. Rasio inovasi sistem pembayaranatauGDP

\begin{tabular}{lc}
\hline \multicolumn{1}{c}{ Cointegrating Eq: } & CointEq1 \\
\hline LN CURRENCY(-1) & 1.000 \\
LN IHK(-1) & 0.000 \\
LN PDB RIIL(-1) & -2.793 \\
& $(0.229)$ \\
SB_DEPO(-1) & {$[-12.169]$} \\
BI_RATE(-1) & 0.000 \\
& 0.004 \\
RTGS PER GDP RIIL (-1) & $(0.0095)$ \\
& {$[0.466]$} \\
& $1.51 \mathrm{E}-05$ \\
KARTU KREDIT PER & $(3.9 \mathrm{E}-05)$ \\
GDP(-1) & {$[0.390]$} \\
& 0.034 \\
ATM DEBIT PER GDP (-1) & $(0.041)$ \\
& {$[0.843]$} \\
& 0.003 \\
EMONEY PER GDP(-1) & $(0.003)$ \\
& {$[1.064]$} \\
& $1.695^{* *}$ \\
C & $(0.689)$ \\
\hline
\end{tabular}

d. Rasio inovasi sistem pembayaranatauM1

\begin{tabular}{lc}
\hline Cointegrating Eq: & Coint Eq1 \\
\hline LN CURRENCY(-1) & 1.000 \\
LN IHK(-1) & 0.000 \\
LN PDB RIIL(-1) & -2.822
\end{tabular}


[-16.297]

0.005

$(0.015)$

[0.353]

BI_RATE(-1) $\quad-0.055$

(0.017)

[-3.227]

0.000

LN IHSG(-1)

8.23E-05

(5.5E-05)

[1.49293]

KARTU KREDIT

$0.243^{* *}$

[3.683]

$0.028^{* *}$

$(0.005)$

[ 5.651]

1.343

(1.347)

[ 0.997]

24.052

Sumber: Output hasil penelitian tahun 2018

Adapun persamaan kointegrasi untuk masing-masing proxy adalah sebagai berikut:

a. Total transaksi inovasi finansial sistem pembayaran

$$
\begin{array}{ll}
\text { Ln }_{\text {Currency }_{t}}= & 2,128 \ln \text { PD Briil }_{t^{-}} \\
& 0,002 \text { SB depo }_{t}+ \\
& 0,060 \ln \text { IHSG }_{t}-0,005 \\
& \ln \text { inovsp }_{t}-16,056
\end{array}
$$

Dari hasil estimasi dapat dilihat bahwa total transaksi inovasi finansial sistem pembayaran tidak signifikan dalam mempengaruhi permintaan akan currency.

b. Rasio M2 per M1

$$
\begin{array}{ll}
\text { Ln }_{\text {Currency }_{t}}= & 2,220 \ln \mathrm{PDB}_{\mathrm{riil}}{ }_{\mathrm{t}}{ }^{-} \\
& 0,014 \mathrm{Sb} \text { depo }_{\mathrm{t}}+0,022 \\
& \text { Birate }_{\mathrm{t}}+0,039 \mathrm{ln} \\
& \text { IHSG }_{\mathrm{t}}-0,0067 \mathrm{M} 2 \text { per } \\
& \mathrm{M}_{\mathrm{t}}-17,225
\end{array}
$$

Dari hasil estimasi dapat dilihat bahwa rasio M2 atau M1 tidak signifikan dalam mempengaruhi permintaan akan currency.

c. Rasio inovasi finansial per GDP

$$
\begin{array}{ll}
\text { Ln } & =2,794 \ln \text { PDB riil } \\
\text { Currency } & -0,04 S B \\
& \text { depo }_{t}-0,000011 \text { RTGS } \\
& \text { per gdp }_{t}-0,034 \text { kartu } \\
& \text { kredit per gdp }_{t}-0,003 \\
& \text { ATM debit per gdp }{ }_{t} \\
& -1,695 \text { emoney per gdp } p_{t}- \\
& 24,294
\end{array}
$$

Dari hasil estimasi dapat dilihat bahwa hanya electronic money yang signifikan mempengaruhi currency, atau dapat disampaikan bahwa dengan adanya peningkatan pada rasio e-money terhadap GDP sebesar $1 \%$ maka akan menurunkan currency sebesar 1,695\%. Hal ini juga telah sesuai dengan teori Baumol (1952) dan Tobin (1956) serta Lippi dan Secchi (2009), dimana dengan adanya electronic money sebagai salah satu substitusi dari currency, maka permintaan akan currency menjadi berkurang.

d. Rasio inovasi finansial per M1

$$
\begin{array}{ll}
\text { Ln }_{\text {currency }_{t}}= & 2,822 \ln \text { PDB riil }-0,005 \\
& \text { BI rate }_{t}+0,055 S B \\
& \text { depo-0,0000823RTGS } \\
& \text { per M1 } 1_{t}-0,243 \text { Kartu } \\
& \text { kredit perM1 }-0,028 \\
& \text { ATM debit card per } \\
& \text { M1 } 1_{t}-1,344 \text { emoney } \\
& \text { per } 1_{t}-25,052
\end{array}
$$

Dari hasil estimasi dapat dilihat bahwa hanya kartu kredit dan ATM atau kartu debet yang signifikan mempengaruhi currency, atau dapat disampaikan bahwa dengan adanya peningkatan pada rasio kartu kredit dan ATM atau kartu debet terhadap M1 sebesar 1 \% maka secara signifikan akan menurunkan currency berturutturut sebesar $0.243 \%$ dan $0.028 \%$. Hal ini juga 
telah sesuai dengan teori dimana dengan adanya kartu kredit dan ATM atau kartu debet yang termasuk sebagai payment system dan sebagai substitusi dari currency, maka permintaan akan currency menjadi berkurang.

Dari analisis untuk masing-masing proxy di atas dapat disimpulkan bahwa secara umum, inovasi finansial sistem pembayaran menurunkan permintaan akan currency, hal tersebut dapat dijelaskan yaitu pada estimasi menggunakan rasio inovasi finansial sistem pembayaran terhadap GDP, electronic money menurunkan currency, kemudian dengan menggunakan proxy rasio inovasi finansial sistem pembayaran terhadap M1, kartu kredit dan kartu debet menurunkan currency secara signifikan.

Dengan menggunakan beberapa proxy sebagai ukuran inovasi finansial sistem pembayaran, menegaskan robustness dari hasil penelitian ini dan membuktikan hipotesis penelitian dimana inovasi finansial sistem pembayaran menurunkan permintaan akan currency dan permintaan uang dalam arti sempitataunarrow money (M1). Hasil penelitian ini selaras dengan hasil riset beberapa peneliti sebelumnya yaitu Attanasio et al. (2002), Stix (2004), Lippi dan Secchi (2009), Yazgan dan Yilmazkuday (2009), Carbo-Valverde dan Rodriguez-Fernandez (2014), Aliha (2017) yang me- nyatakan bahwa inovasi finansial sistem pembayaran memiliki pengaruh negatif terhadap curren$c y$. Demikian juga hasil penelitian ini sesuai dengan hasil riset dari Lieberman (1977), Bordo dan Jonung (1987), Pramono et al. (2009), Sahabat (2009) dan Nagayasu (2012) yang menyatakan bahwa inovasi finansial sistem pembayaran memiliki pengaruh negatif terhadap narrow money (M1).

\section{SIMPULAN DAN SARAN Simpulan}

Berdasarkan hasil penelitian yang dilakukan dapat disimpulkan bahwa secara umum perkembangan inovasi finansial sistem pembayaran dapat mempengaruhi currency, dan permintaan uang dalam arti sempit (M1) untuk periode tahun 2007 sampai dengan tahun 2017. Pengaruh perkembangan inovasi finansial sistem pembayaran terhadap permintaan currency serta permintaan uang dalam arti sempit (M1) dapat dijelaskan sebagai berikut:

Pertama, hasil estimasi pengaruh inovasi finansial sistem pembayaran terhadap currency dan M1 dimana pengaruh inovasi finansial sistem pembayaran terhadap currency dan M1 adalah negatif, sesuai dengan Teori Baumol (1952) dan Tobin (1956) dan teori yang disampaikan Lippi dan Secchi (2009) yang menyatakan bahwa dengan adanya peningkatan teknologi dapat mengurangi biaya transaksi sehingga currency dan M1 yang dibutuhkan juga menurun.

Kedua, perkembangan inovasi finansial sistem pembayaran menurunkan permintaan currency, hal ini sesuai dengan hasil estimasi yaitu dengan menggunakan rasio inovasi sistem pembayaran terhadap GDP, peningkatan penggunaan uang elektronik atau electronic money menurunkan permintaan currency, dan dengan menggunakan proxy rasio inovasi sistem pembayaran terhadap M1, peningkatan penggunaan kartu kredit dan ATM atau kartu debet menurunkan permintaan akan currency.

Ketiga, perkembangan inovasi finansial sistem pembayaran menurunkan permintaan M1, hal ini sesuai dengan hasil estimasi yaitu dengan menggunakan proxy volume transaksi, peningkatan penggunaan electronic money menurunkan permintaan akan M1, kemudian dengan menggunakan proxy rasio inovasi sistem pembayaran terhadap GDP, peningkatan penggunaan kartu kredit dan electronic money menurunkan permintaan M1, selanjutnya dengan menggunakan proxy nilai transaksi, peningkatan penggunaan ATM atau kartu debet menurunkan permintaan M1, dan dengan menggunakan proxy rasio inovasi sistem pembayaran terhadap M1, peningkatan penggunaan kartu kredit menurunkan permintaan akan M1.

Keempat, proxy yang sesuai untuk mengukur hubungan antara inovasi finan- 
sial sistem pembayaran dengan permintaan uang dalam arti sempit (M1) berdasarkan speed of adjustment yang tercepat adalah menggunakan nilai transaksi, menggunakan volume transaksi, serta rasio inovasi finansial sistem pembayaran terhadap GDP.

\section{Saran}

Dari hasil penelitian, implikasi untuk otoritas moneter yang meneliti dan memprediksikan money demand, perlu mempertimbangkan inovasi finansial sistem pembayaran karena dari penelitian yang dilakukan, telah terbukti bahwa inovasi finansial sistem pembayaran memiliki pengaruh terhadap money demand. Kemudian dalam melakukan penelitian mengenai money demand, otoritas moneter perlu menggunakan proxy yang tepat dan menghasilkan perhitungan yang sesuai dan mencerminkan perkembangan inovasi finansial sistem pembayaran yang paling mutakhir.

Dengan belum tersedianya biaya transaksi atau brokerage cost sesuai dengan pendekatan Baumol (1952) dan Tobin (1956) serta Lippi dan Secchi (2009), ke depannya diharapkan otoritas moneter atau regulator terkait dapat menyediakan data biaya transaksi atau brokerage cost untuk masingmasing jenis simpanan dan tipe inovasi finansial sistem pembayaran agar dapat digunakan sebagai sumber data dalam penelitian selanjutnya yang terkait dengan inovasi finansial sistem pembayaran.

\section{DAFTAR PUSTAKA}

Akhand, H. dan R. Milbourne. 1986. Credit Cards and Aggregate Money Demand. Journal of Macroeconomics 8: 471-478.

Aliha, P. M. 2017. Investigating the Effect of Financial Innovation on the Demand for Money in Malaysia Using the ARDL Approach to Cointegration. Regional Science Inquiry IX(1): 177-193.

Alvarez, F. dan F. Lippi. 2009. Financial Innovation and The Transactions Demand for Cash. Econometrica 77: 363-402.

Attanasio, O. P., L. Guiso, dan T. Jappelli. 2002. The Demand for Money, Financial
Innovation, and The Welfare Cost of Inflation: an Analysis With Household Data. Journal of Political Economy 110: 317-351.

Arrau, P. dan J. D. Gregorio. 1993. Financial Innovation and Money Demand: Application to Chile and Mexico. The Review of Economics and Statistics 75(3): 524-530.

Arrau, P., J. D. Gregorio, C. Reinhart, dan P. Wickham. 1995. The Demand for Money in Developing Countries: Assessing the Role of Fnancial Innovation. MPRA Paper 14096: 1-30.

Baba, Y., D. F. Hendry, dan R. M. Starr. 1992. The Demand for M1 in The U.S.A., 19601988. Review of Economic Studies 59: 2561.

Baumol, W. J. 1952. The Transactions Demand for Cash: An Inventory Theoretic Approach. Quarterly Journal of Economics 66: 545-556.

Bordo, M. dan L. Jonung. 1987. The LongRun Behavior of the Velocity of Circulation: The International Evidence, Cambridge, University Press.

Carbo-Valverde, S., F. Rodriguez-Fernandez. 2014. ATM Withdrawals, Debit Card Transactions at The Point-of-Sale and The Demand for Currency. SERIES 5: 399-417.

Cho, D. dan W. Miles. 2007. Financial Innovation and The Stability of Money Demand in Korea. Southwestern Economic Review: 51-59.

Columba, F. 2009. Narrow Money and Transaction Technology: New Disaggregated Evidence. Journal of Economics and Business 61: 312-325.

Daniels, K. N. dan N. B. Murphy. 1994. The Impact of Technological Change on The Currency Behavior of Households: an Empirical Cross-Section Study. Journal of Money, Credit and Banking 26: 867-874.

David, B., A. François, dan P. Waelbroeck. 2016. Debit Card and Demand for Cash. Journal of Banking and Finance 73: 55-66.

Duca, J. V. dan W. C. Whitesell. 1995. Credit Cards and Money Demand: A Cross- 
sectional Study. Journal of Money, Credit and Banking 27(2): 604-623.

Fischer, A. M. 2007. Measuring Income Elasticity for Swiss Money Demand: What do the Cantons Say About Financial Innovation?. European Economic Review 51: 1641-1660.

Fujiki, H. dan C. B. Mulligan. 1996. A Structural Analysis of Money Demand: Cross-Sectional Evidence From Japan. Bank of Japan Monetary and Economic Studies 14: 53-78.

Handa, J. 2009. Monetary Economics. 2 $2^{\text {nd }}$ edition. Routledge Taylor \& Francis Group. New York.

Nagayasu, J. 2012. Financial Innovation and Regional Money. Applied Economics 44(35): 4617-4629.

Lieberman, C. 1977. The Transactions Demand for Money and Technological Change. Review of Economics and Statistics 59: 307-317.

Lippi, F. dan A. Secchi. 2009. Technological Change and The Households Demand for Currency. Journal of Monetary Economics 56: 222-230.

Milbourne, R. 1986. Financial Innovation and The Demand for Liquid Assets: Note. Journal of Money, Credit and Banking 18 (4): 506-511.

Mulligan, C. B. dan X. Sala-i-Martin. 1992 US Money Demand: Surprising CrossSectional Estimates. Brookings Papers on Economic Activity 2: 285-329.

Oyelami, L. O. dan D. O. Yinusa. 2013. Alternative Payment Systems: Implication For Currency Demand and Monetary policy in Developing Economy: a Case Study of Nigeria. Inter- national Journal of Humanities and Social Science 3(20): 253-260.

Pramono, B., T. Yanuarti, P. D. Purusitawati, dan Y. T. Emmy. 2006. Dampak Pembayaran Non Tunai Terhadap Perekonomian dan Kebijakan Moneter. Working Paper Bank Indonesia 11: 1-60.

Rinaldi, L. 2001. Payment Cards and Money Demand in Belgium. CES Discussion Paper DPS 01.16. KU Leuven.

Sahabat, I. 2009. Pengaruh Inovasi Sistem Pembayaran Terhadap Permintaan Uang di Indonesia. Tesis. Program Pascasarjana Ilmu Ekonomi, Universitas Indonesia. Jakarta.

Syarifuddin, F., A. Hidayat, dan T. Tarsidin. 2009. Dampak peningkatan pembayaran non-tunai terhadap perekonomian dan implikasinya terhadap pengendalian moneter di Indonesia. Buletin Ekonomi Moneter dan Perbankan 11(4): 369-402.

Shiva, R. K. dan R. K. Durai. 2017. Impact of Credit Cards and Debit Cards on Currency Demand and Seigniorage: Evidence from India. Academy of Accounting and Financial Studies Journal 21(3): 1-15.

Stix, H. 2004. How Do Debit Cards Affect Cash Demand? Survey Data Evidence. Empirica 31: 91-115.

Tobin, J. 1956. The Interest Elasticity of Transactions Demand for Cash. Review of Economics and Statistics 38(3): 241-247.

Tufano, P. 2003. Financial Innovation. The Handbook of the Economics of Finance. North Holland. Boston.

Yazgan, M. E., dan H. Yilmazkuday. 2009. The Effects of Credit and Debit Cards on the Currency Demand. Applied Economics 41(16): 2115-2123. 